\title{
The Strategy Research of Emotion Teaching Skills Application in Ideological and Political Course
}

\author{
Dai Jian-qiang \\ Jiangxi University of Technology
}

Abstract - In recent years, the emotion teaching mode has been paid more and more attention by the academic, which is not only because it can promote the comprehensive development of cognitive quality and emotional quality, but also due to its ability to meet humans' needs, realize the social formation of the moral value idea that people pursue, even can get rid of the defects of pure intellectual education, and truly achieve the education of people and educating people. There are quite a lot of research documents about emotion teaching, but the research on the emotion teaching skills in ideological and political course is rare. The purpose of this paper is to further clarify the connotation and structure of emotion teaching skills in ideological and political course, initially propose application strategy in emotion teaching skills, enrich research's content of emotion teaching, and further expand the scope of ideological and political course emotion research, provide useful entry point for further study of classroom teaching and research.

Keywords-Ideological and political course; Emotion teaching skills; Strategy

\section{INTRODUCTION}

Ideological and political course is the national moral education curriculum, which should be more fun and more popular in students, but it lost the original vitality due to the influence of traditional rational education. The main reasons are the school does not face the nature of this course or develop or research the contents combining with the nature of moral education, the characteristics of emotion guidance and the content of life. Ideological and political course is a course that can cultivate students' patriotism, guide and establish a scientific outlook on world outlook on life, help students develop high moral quality, create moral person. In actual teaching, teachers often despise these objectives but only paying attention to

\author{
Xie Ai-min \\ Jiangxi University of Technology
}

achieve the goal of knowledge, which makes students cannot practise the moral knowledge which they have learned. The course trains a number of people who have moral ideas but being lack of truly moral.

Few scholars have made studies of emotion teaching skills. The author tries to combine theory and practice of classroom teaching to make in-depth research of emotion teaching: theoretical the practices, systematical theoretical knowledge, and makes systematic knowledge have a profound impact and practical guidance on teaching practice. Then the author clarifies the connotation and structure of emotional teaching skills which is conducive to enrich the content of emotional education research and expands the scope of emotion teaching in ideological and political course, which provides a reference point for further research.

\section{THE MEANING OF EMOTION TEACHING SKILLS IN IDEOLOGICAL AND POLITICAL COURSE}

Emotion teaching skills in ideological and political course is defined as follows: teachers use a series of teaching experience and behavior in emotion factors from teaching resources skillfully in order to achieve the goal of emotional education in the ideological and political (moral) teaching process. Emotion theory thinks that the individual needs to produce emotion because of his own needs, while the formation of the mood and the performance of the process will also produce the unique needs of the individual. In moral education, teachers make the moral model by direct words and deeds, or make education of expression, posture, tone of emotion transfer, emotional contagion, or make the media, public opinion, customs with a strong emotional color to cause people's recognition of moral value, resonance and yearning.

We should pay attention to ideological and moral 
course during the teaching process and pay more attention to enrich students' moral experience to improve students' moral practice ability. Teachers should understand students' life experiences and learning needs, use appropriate methods to guide students to carry out moral practice; use experience and comprehension to form students' correct moral values and good behavior, which shows that in order to make students be more meaningful in learning, strengthen the emotional experience and deepen moral sentiment, develop the students' comprehensive development, ideological and political (moral) teachers are very necessary to master and skilled use of emotional teaching skills, which can promote the formation of students' correct ideas and the development of good moral quality.

\section{THE STRUCTURES OF EMOTION TEACHING SKILLS IN} IDEOLOGICAL AND POLITICAL COURSE

The structure of emotion teaching: induction, cultivation, inspiration and regulation. Induction is to mobilize students' learning motivation and enthusiasm to learn, which lays a foundation for the development of teaching; Cultivation is to cultivate students' noble moral sentiment and life sentiment while promoting cognition; Inspiration is to enhance students' self-confidence in learning persistently and to stimulate the learning power; Regulation is to avoid too high or too low emotion discourages the cognitive learning or the development of emotional qualities of students, to ensure students' emotional stability and the smooth implementation of emotional education. In this paper, the emotion teaching skills of ideological and political course is divided into two aspects: emotion expression skills and emotion regulation skills.

\section{A. Emotion expression skills}

The so-called emotional expression skills are that teachers can effectively express and display the emotional factors through the multiple subjects in the teaching process of ideological and political course. After the emotion generating, the key step is the expression of emotion. From a psychological point of view, language is only a way of content, thinking and emotional expression, as well as some non-verbal expressions, such as faces, eyes, gestures, postures, behaviors, actions and so on.

\section{B. Emotion regulation skills}

Emotion regulation skills are defined as: teachers use emotional factors to regulate both themselves and students in the teaching process, which is always in a positive state of teaching or learning, which does not only contain teachers regulating students' emotion to make it conducive to learning, but also regulating the emotion of themselves in order to facilitate teaching.

\section{THE SIGNIFICANCE OF USING EMOTION TEACHING SKILLS IN IDEOLOGICAL AND POLITICAL COURSE}

\section{A. Being conducive to the realization of curriculum objectives}

The improvement of emotional teaching skills must be able to make the ideological and political (moral) course teaching be full of energy, active classroom atmosphere, and harmonious teacher-student relationship, which will strengthen the teacher's emotional appeal to students and help teachers to guide students' emotional attitude values smoothly, and makes teachers and students emotional resonance be more natural and harmonious, even highlights the authenticity of classroom teaching.

\section{B. Being conducive to the optimization of classroom teaching effects}

Teachers should use the emotion teaching skills to put the value view based knowledge field penetrate into the learning by emotion generation, emotion expression, emotion cultivation and emotion regulation of all aspects of the infection influence. Use the method of moisten things silently penetration into the classroom and the method of sweetness and light moisture to the hearts of students, which is conducive to promote students to grasp the theory knowledge study.

\section{Being conducive to the development of physical and mental health of students}

In contemporary society, psychological problems are frequently seen, no matter being disgusted with learning, treason, depression or inhibition, which greatly affects the development of physical and mental health of students. The school education must make a difference that can make the mood of the students released, so that the flowers of the motherland persecuted. The intercalation of ideological and political (moral) course is not only to 
complete the task of theoretical and ideological and moral education, but also to be ignored careful observation and correct guidance from the psychological state of students.

\section{CONCLUSION}

The full mobilization of the emotion factors really realizes the deep excavation of the curriculum resources. The practical implementation of the emotional teaching fully respects the height of the course teaching. The improvement of emotional teaching skills can really promote the improvement of classroom teaching effect. This paper makes a detailed discussion of the emotional teaching skills, which provides a basis for readers to understand the emotional teaching skills, and is helpful to guide the idea of setting up emotional teaching in practical teaching and to further clarify the connotation of emotion teaching skills and reasonable use of emotion factors in the implementation of teaching, and has certain guiding significance in the practical teaching. However, there are still lots of shortcomings of this paper, such as the in-depth joints with the subject teaching are not enough in the elaboration of enhanced emotional teaching skills and the analysis of the characteristics of the teaching skills of this discipline is not enough. Therefore, the subject of this paper should be studied and improved further.

\section{REFERENCES}

[1] Wang X. On the Current Ideological and Ethical Construction of College Students[J]. Journal of Shandong Youth University of Political Science, 2015.

[2] Li Q H, College Z T. On the Training of College Students' Ideological and Ethical Qualities Thepath of Political Education In Network[J]. Journal of Hubei Correspondence University, 2015.

[3] Zhou, Nie, and H. N. University. "Study on Building a Socialist Ideological and Ethical System and the Youth's Responsibility." Journal of Weinan Normal University (2014).

[4] Song, Pei. "On the Period of Social Transformation Socialist Ideological and Ethical construction." Journal of Hunan Industry Polytechnic (2012).

[5] Hou L. Discussion on the Influence of Traditional Culture on Ideological and Ethical Standard[J]. Value Engineering, 2011

[6] Zhu, Mei Fen. "Analyzing and Rethinking the Teaching Effect of "Ideological and Ethical Cultivation and Legal Basis"." Journal of Hefei Normal University (2011).

[7] Zhou, Guang Fang. "On Teachers' Role Positioning in Ideological and Ethical Education." Journal of Xuzhou Normal University (2011).

[8] Dong-Hua, L. I. "Application and Exploration of Project Teaching in Ideological and Ethical Education and the Legal Basis." Journal of Guangzhou City Polytechnic (2011).

[9] Zhang, Zongming. "Enhance Education of Chinese Medicine Culture,Raise Ideological and Ethical Standards of College Students." Medicine \& Society (2010).

[10] Chun-Hua L I, Da-Hai Y U. The Efficient way to Strengthen New Rural's Ideological and Ethical Construction[J]. Journal of Chongqing University of Arts \& Sciences, 2010.

[11] Fan J F, Wang D M. Comment on the value significance of the filial duty in the ideological and ethical building $[\mathrm{J}]$. Journal of Xian University of Posts \& Telecommunications, 2010.

[12] Qin M, Ye S. A Probe into the Basic Situation of Development of the Minors'Ideological and Ethical Standards[J]. Journal of Chizhou College, 2010. 